\title{
Salvage radiotherapy with simultaneous integrated boost in non small-cell lung cancer patients with mediastinal relapse after surgery: a pilot study
}

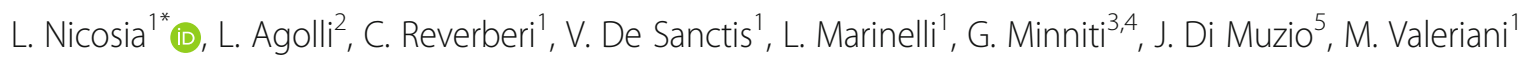
and M. F. Osti ${ }^{1}$

\begin{abstract}
Background: The aim of our study was to evaluate feasibility, toxicity profile and local control of salvage intensity modulated radiotherapy (IMRT) delivered with simultaneous integrated boost (SIB) associated or not to concomitant weekly cisplatin in patients affected by NSCLC with mediastinal nodal recurrence after surgery. Patterns of recurrence, outcomes and prognostic factors were assessed.

Methods: Fourteen consecutive patients received 25 fractions of 50Gy/2Gy to the elective nodal stations and boost up to $62.5 \mathrm{~Gy} / 2.5 \mathrm{~Gy}$ to the macroscopic lymph node metastases. Concomitant weekly cisplatin $\left(40 \mathrm{mg} / \mathrm{m}^{2}\right)$ was administered to 8 (57.1\%) patients.

Results: Five (35.7\%) patients experienced grade 2 pneumonitis and 5 (35.7\%) patients had grade 2 esophagitis. One case of grade 3 pneumonitis occurred and was successfully treated with antibiotics and steroids with no sequelae. No patient recurred locally in the boost volume (local control 100\%). Loco-regional control was 79\% with 3 patients that developed nodal recurrence principally marginal to the elective volume. Seven patients developed distant metastases. Median PFS was 7 months. The nodal involvement of station 7 was associated to a significantly lower median metastasis-free survival (4 months vs. not reached, $p=0.036$ ).

Conclusions: Salvage radiotherapy with IMRT-SIB is a feasible and a well-tolerated treatment option for mediastinal recurrent NSCLC after surgery. The role of more intensified radiation regimens and association to systemic therapy remain to be evaluated in larger cohorts.
\end{abstract}

Keywords: Mediastinal recurrent NSCLC, Post-surgical relapse, Salvage radiotherapy, Intensity modulated radiotherapy with simultaneous integrated boost

\section{Background}

Surgery is the gold standard in the treatment of resectable stage I-IIIA non small-cell lung cancer (NSCLC) with 5 -years survival rates of $92 \%$ for early stage and $26 \%$ for locally advanced disease, respectively [1]. Relapse after surgery may occur in up to $50 \%$ of patients depending on the pathological stage [2] and recurrence occurs mainly in the mediastinal lymph nodes in $8-37 \%$

\footnotetext{
* Correspondence: lucanicosia.rg@gmail.com

'Department of Radiation Oncology, Sant'Andrea Hospital, "Sapienza" University of Rome, Via di Grottarossa 1035-1039, 00189 Rome, Italy Full list of author information is available at the end of the article
}

of cases [3, 4]. Recent data showed that the routine use of post-operative radiotherapy (PORT) after complete resection has a negative effect on survival [5], therefore, the role of mediastinal irradiation can be evaluated in the case of loco-regional relapse.

Treatment options in of mediastinal recurrence could be surgery, chemotherapy, radiotherapy (RT), or a combination. Nevertheless, the best approach remains uncertain. Some studies reported long-term survival and in some cases even cure after intensive local treatment in a selected population of patients with mediastinal

(c) The Author(s). 2018 Open Access This article is distributed under the terms of the Creative Commons Attribution 4.0 International License (http://creativecommons.org/licenses/by/4.0/), which permits unrestricted use, distribution, and reproduction in any medium, provided you give appropriate credit to the original author(s) and the source, provide a link to the Creative Commons license, and indicate if changes were made. The Creative Commons Public Domain Dedication waiver (http://creativecommons.org/publicdomain/zero/1.0/) applies to the data made available in this article, unless otherwise stated. 
lymph node recurrence after surgery and no distant metastases [6-8].

Systemic therapy alone is necessary, but not very efficient to contain the macroscopical active sites of disease. An aggressive local therapy such as surgery or high-dose $\mathrm{RT}$ is required. The reported 5-years survival in patients with loco-regional relapse/persistence treated with surgery ranged from 13 to $25 \%[9,10]$. Unfortunately, in patients already resected a second surgery is not always feasible. This category of patients often presents with related-symptoms and associated comorbidities; RT could represent a valid alternative comparable to surgery in terms of survival and with acceptable toxicity rates $[11,12]$. Most of the studies evaluating this topic are limited from the inhomogeneous treatment schedules and the use of old irradiation techniques. The advantage of modern techniques is to escalate the dose to the tumor and improve toxicity profile in order to obtain good tumor control and better tolerance rates.

We reported feasibility, safety and local control of NSCLC patients presenting post-operative mediastinal nodal recurrence, who received salvage intensity modulated radiotherapy - simultaneous integrated boost (IMRTSIB) with curative intent.

\section{Methods}

We retrospectively reviewed a series of patients with NSCLC and post-operative mediastinal nodal relapse, treated with salvage IMRT-SIB associated or not to concomitant chemotherapy.

Pre-treatment evaluation included: physical examination, total body computed tomography (CT) scan and 18-fluordeoxyglucose positron emission/ CT (18FDGPET/CT), both not older than 1 month, lung function test, total blood count and kidney function test.

\section{Treatment characteristics and planning}

All patients underwent pretreatment planning $\mathrm{CT}$ in the supine position using a wing-board system for immobilization. Planning CT images were matched with contrast medium diagnostic CT and 18FDG-PET/CT images using automatic matching for the target volume delineation. Gross Tumor Volume (GTV) encompassed the positive mediastinal lymph nodes (PET positive and/or $\geq$ $10 \mathrm{~mm}$ ). The elective clinical target volume (CTV-elective) encompassed the nodal stations based on primary tumor location: stations $2 \mathrm{R}, 4 \mathrm{R}, 7$ and $10 \mathrm{R}$ for tumors in the superior right lobe (SRL) and middle lobe (ML); stations $4 R, 7,10 R$ for tumors of the inferior right lobe (IRL): stations $2 \mathrm{~L}, 4 \mathrm{~L}, 5,6,7,10 \mathrm{~L}$ for tumors in the superior left lobe (SLL); and stations: 4 L, 5, 6, 7, $10 \mathrm{~L}$ for tumors located in the inferior left lobe (ILL). Afterwards, GTV and CTV were expanded $5 \mathrm{~mm}$ and $7 \mathrm{~mm}$ in all directions to generate planning target volume 1 (PTV1) and PTV2, respectively.

All patients were treated with IMRT-SIB technique using multiple coplanar and non-coplanar fields. The margins were maintained small in order to avoid potential toxicities and an image guidance with kilovolt onboard cone beam CT was performed daily in order to guarantee an adequate positioning of the patients. The images from the cone-beam CT were matched to the planning CT prior to each treatment based on the initial automatic bone alignment, followed by a soft tissue/target alignment. Radiation therapy was delivered by a linear accelerator using 6-MV photon beams. The radiation treatment regimen consisted of 50Gy in 25 fractions of 2Gy each to the PTV2, with a simultaneous integrated boost of $62.5 \mathrm{~Gy}$ in 25 fractions of $2.5 \mathrm{~Gy}$ each on the PTV1.

The BED (biological equivalent dose 10 [BED10]) at the PTV1 was 78Gy. The dose was prescribed at the $95 \%$ isodose with normalization to the maximal dose. The treatment was administered 5 times per week for 5 weeks. Dose constraints for critical normal structures are reported in Table 1. Concomitant chemotherapy consisted in weekly cisplatin $\left(40 \mathrm{mg} / \mathrm{m}^{2}\right)$, given on days $1,6,11,16,21$. Chemotherapy was not administered in cases of inadequate renal function or refusal by the patients.

\section{Follow-up and statistics}

All patients underwent weekly clinical evaluations and routine blood examinations during radiation therapy. Treatment-related toxicities were graded according to the CTCAE v 4.0 scale. Follow-up was performed every 3 months for the first 2 years after RT and then every 6 months afterward. A total body CT with contrast medium was performed at 1 month after RT and every

Table 1 Dosimetry and dose constraints to critical normal structures

\begin{tabular}{ll}
\hline PTV1 & Median 45.8 Gy (41.8-48.2Gy) \\
PTV2 & Median 59.8 Gy (57.3-60.1Gy) \\
Mean Lung Dose & Median 10.3 Gy (6-15.3Gy) \\
Bilateral lung V20 & Median 16.45\% (7.6-33.1\%) \\
Ipsilateral Lung V5 & Median 62.45\% (39.9-81.1\%) \\
Ipsilateral Lung V20 & Median 28\% (17.9-42.5\%) \\
Controlateral Lung V5 & Median 45.75\% (2.3-69.1\%) \\
Controlateral lung V20 & Median 16.35\% (0.6-48\%) \\
Heart V5 & $20.2 \%(7.1-66.1 \%)$ \\
Heart V30 & $2.75 \%(0-12.3 \%)$ \\
Esophagus V11.5 & $36 \%(21.1-68.5 \%)$ \\
Esophagus V18 & $45.15 \%(27.3-69.1 \%)$ \\
Esophagus V27 & $52.35 \%(26.9-69.8 \%)$ \\
\hline
\end{tabular}


6 months afterward. A post treatment 18FDG-PET/CT was performed at 3 months after RT and if there was suspicion for tumor recurrence/progression at CT images. The local/regional recurrence was based on new evidence or marginal regrowth of the disease on follow-up CT scans and higher uptake on the 18FDG-PET/CT.

Statistical analysis was performed using SPSS, version 16.0, software (SPSS, Inc., Chicago, IL). Primary endpoints were toxicity and local control. Secondary endpoints were pattern of failure, survivals and possible prognostic factors. Local progression-free survival (LPFS) was defined as the time to in-field or marginal regrowth of the disease or death. PFS was defined as the time to any progression or death. Metastasis-free survival (MFS) was defined as any site of distant progression (including the lungs) or death. Survivals were calculated from the date of initial RT and were estimated using the Kaplan- Meier method. Clinical prognostic factors such as age, sex, histological subtype, number and station of involved lymph nodes, PTV size, previous chemotherapy, and type of response were included in the statistical analysis. Univariate analysis was performed to determine significant prognostic factors using the log-rank test. A $p$-value $<.05$ was considered statistically significant.

\section{Results}

\section{Patients' characteristics}

From January 2014 to September 2016, 14 consecutive patients with NSCLC and post-operative mediastinal nodal relapse were treated with salvage IMRT-SIB associated or not to concomitant chemotherapy.

Median age was 68 years (range, $51-78$ years). Eleven (78.5\%) patients were male, $3(21.5 \%)$ were female. Patients had ECOG (Eastern Cooperative Oncology Group Criteria) $\leq 2$ and received no previous thoracic RT. All patients underwent surgery and mediastinal lymphadenectomy before salvage RT. Five (35.7\%) patients received pre-operative chemotherapy with platinum-based regimen and $9(34.3 \%)$ patients received subsequently platinum-based adjuvant chemotherapy. The median interval between primary surgery and mediastinal recurrence was 10 months (range, 2-18 months). Patient's characteristics are summarized in Table 2 .

\section{Local control and toxicity profile}

Five (35.7\%) patients experienced grade 2 pneumonitis and $5(35.7 \%)$ patients had grade 2 esophagitis. One patient developed grade 1 leucopenia and grade 2 thrombocytopenia; radiochemotherapy was prudently interrupted for 5 days until achievement of normal blood count and was subsequently continued with no other interruption or toxicity. No treatment-related deaths occurred. One (7.1\%) case of G3 pneumonitis occurred and was then successfully treated with
Table 2 Patients' characteristics $(n=14)$

\begin{tabular}{|c|c|}
\hline Age (median, years) & 68 \\
\hline Range (years) & $51-78$ \\
\hline \multicolumn{2}{|l|}{ Sex } \\
\hline - Male & $11(78.5)$ \\
\hline - Female & $3(21.5)$ \\
\hline \multicolumn{2}{|l|}{ Histology } \\
\hline - Adenocarcinoma & $12(85.6)$ \\
\hline - Squamocellular & $2(14.4)$ \\
\hline \multicolumn{2}{|l|}{ Pathological Stage } \\
\hline$\cdot \mid \mathrm{B}$ & $2(14.4)$ \\
\hline$\cdot \| A$ & $6(42.8)$ \\
\hline$\cdot \| A$ & $6(42.8)$ \\
\hline \multicolumn{2}{|l|}{ Neoadjuvant Chemotherapy } \\
\hline - Platinum-based & $5(35.7)$ \\
\hline • No & $9(64.3)$ \\
\hline \multicolumn{2}{|l|}{ Initial surgery } \\
\hline • Lobectomy + LAD & $13(92.8)$ \\
\hline - Atypical resection + LAD & $1(7.2)$ \\
\hline \multicolumn{2}{|l|}{ Adjuvant Chemotherapy } \\
\hline - Platinum-based & $8(57.2)$ \\
\hline • Vinorelbine monotherapy & $1(7.1)$ \\
\hline$\cdot$ No & $5(35.7)$ \\
\hline \multicolumn{2}{|c|}{$\mathrm{N}^{\circ}$ of pathological nodal stations involved at diagnosis } \\
\hline 0 & $2(14.3)$ \\
\hline 1 & $6(42.8)$ \\
\hline 2 & $3(21.5)$ \\
\hline 3 & $1(7.1)$ \\
\hline 4 & $2(14.3)$ \\
\hline
\end{tabular}

LAD: lymphadenectomy

antibiotics and steroids with no sequelae. The patient had a known diagnosis of chronic obstructive pulmonary disease (COPD) and a probable reactivation of the disease could be hypothesized, also considering the retained dose constraints for the lung (V20 29.9\%, MLD 15.1\%). See Table 3.

Five (35.7\%) patients did not receive concomitant chemotherapy for inadequate kidney function or refusal. No patient recurred locally in the boost volume (local control 100\%). Loco-regional control was $79 \%$ with three patients that developed nodal recurrence principally marginal to the elective volume.

\section{Patterns of relapse, survival and prognostic factors}

After a median follow up of 12 months (range: 328 months), 3 patients developed regional failure: one patient had lymph node metastases in station 7 and 5 marginal to the elective volume; 2 patients developed 
Table 3 Acute and late toxicity (sec. CTCAE 4.0)

\begin{tabular}{llll}
\hline & G1-2 & G3 & G4-5 \\
\hline Acute toxicity & & & \\
Pneumonitis & $5(35.7)$ & $1(7.1)$ & 0 \\
Esophagitis & $5(35.7)$ & 0 & 0 \\
Nausea & $3(21.5)$ & 0 & 0 \\
Leukopenia & $1(7.1)$ & 0 & 0 \\
Thrombocytopenia & $1(7.1)$ & 0 & 0 \\
Fatigue & $2(14.3)$ & 0 & 0 \\
Skin erithema & $1(7.1)$ & 0 & 0 \\
Late toxicity & & & \\
Fibrosis & $4(28.6)$ & 0 & 0 \\
\hline
\end{tabular}

lymph node metastasis in station 7: in the elective irradiated volume and marginal to the elective volume, respectively. Seven patients developed distant progression: 2 patients had solitary brain metastases, one patient had diffuse lung and nodal metastases, one patient developed diffuse liver metastases, one patient had bone and brain metastases and one patient had bone metastases. See patterns of relapse in Table 4.

At the time of the analysis, 6 (42.8\%) patients were deceased: 4 of them due to disease progression, 2 of them had a worsening of the known COPD and one died of massive thrombosis. Median PFS was 7 months (range: 3-28 months) and 1-year PFS was 39.7\%. Median LPFS was 26 months (range: 3-28 months) and 1-year LPFS was $80 \%$. Median MFS was 9 months (range: 328 months) and 1 year MFS was $46.3 \%$.

Concomitant chemotherapy did not significantly predict for a longer LPFS, PFS or MFS. The nodal involvement of station 7 was associated to a significantly lower median MFS ( 4 months vs. not reached, $p=0.036$ ). No other significant factors were found.

\section{Discussion}

This is a pilot study of patients affected by NSCLC presenting with post-operative mediastinal lymph node relapse and treated with IMRT-SIB technique associated or not to weekly cisplatin. The purpose of the study was to establish the safety and feasibility of the hypofractionated RT schema. Our results are in accordance to those presented by other authors. Bae et al. [12] treated 64 patients between 1994 and 2007 , with a median $\mathrm{BED}_{10}$ of 70.2 Gy (range 51.5-85.8 Gy) delivered with various fractionations and concomitant chemotherapy in $21.9 \%$ patients. Toxicity profile was characterized by one (1.6\%) case of grade 4 pneumonitis and 6 (9.4\%) cases of grade3 pneumonitis. Kim et al. [13] reported 5.3\% and $3.5 \%$ rates of grade 3 pneumonitis and esophagitis, respectively, in 57 NSCLC patients with loco-regional relapse after surgery treated with different RT schedules (median $\mathrm{BED}_{10} 79.2 \mathrm{~Gy}$; range 58.5-84 Gy) and concomitant chemotherapy (73.7\% of patients).

Our treatment schedule was well tolerated, with only one case of grade 3 pneumonitis in a patient with known COPD. The use of IMRT in our population can explain the relatively low rate of severe toxicity, as compared to the higher rates $(2.6-65.5 \%)$ of previous studies, where 3D-CRT, techniques or more toxic chemotherapeutic regimens were used. A summary of previous studies showing the toxicity profile, type of treatment and RT regimens is reported in Table 5 .

Table 4 Patterns of recurrence and treatment

\begin{tabular}{|c|c|c|c|c|c|c|c|c|c|}
\hline Patient & Age & $\begin{array}{l}\text { Site of Boost } \\
\text { Volume }\end{array}$ & CCT & $\begin{array}{l}\text { Dosis } \\
\text { SIB (Gy) }\end{array}$ & $\begin{array}{l}\text { Volume/Nolume } \\
\text { SIB (cc) }\end{array}$ & $\begin{array}{l}\text { Local relapse } \\
\text { (boost) }\end{array}$ & $\begin{array}{l}\text { Nodal regional } \\
\text { relapse }\end{array}$ & $\begin{array}{l}\text { Distant } \\
\text { recurrence }\end{array}$ & $\begin{array}{l}\text { Therapy after } \\
\text { recurrence }\end{array}$ \\
\hline 1 & 78 & $2 L, 4 L, 5,6$ & Yes & $50 / 62.5$ & $323.24 / 80$ & No & No & Lung, nodes & BSC \\
\hline 2 & 55 & $4 \mathrm{R}, 10 \mathrm{R}$ & Yes & $50 / 62.5$ & $166.48 / 52.43$ & No & 7 & Brain, bone & Palliative RT \\
\hline 3 & 67 & $4 \mathrm{R}, 5,10 \mathrm{R}$ & No & $50 / 62.5$ & 213.81/14.91 & No & No & & \\
\hline 4 & 78 & $r T, 10 R$ & No & $50 / 62.5$ & 201.06/11.35 & No & 7 and 5 & & BSC \\
\hline 5 & 75 & $2 R, 4 R, 5$ & Yes & $50 / 62.5$ & $402.31 / 98.14$ & No & No & & \\
\hline 6 & 69 & $5,6,10 L$ & No & $50 / 62.5$ & $203.58 / 76.48$ & No & No & & \\
\hline 7 & 56 & $10 R$ & Yes & $50 / 62.5$ & $64.16 / 5.42$ & No & No & & \\
\hline 8 & 55 & $2 L, 4 R, 6$ & Yes & $50 / 62.5$ & $148.86 / 10.29$ & No & No & & \\
\hline 9 & 51 & $2 \mathrm{R}, 4 \mathrm{R}, 5,7,10 \mathrm{R}$ & No & $50 / 62.5$ & $313.01 / 193.46$ & No & No & & \\
\hline 10 & 57 & $2 \mathrm{R}, 4 \mathrm{R}, 5,7,10 \mathrm{R}$ & No & $50 / 62.5$ & $408.43 / 95$ & No & No & Brain & SRS 9 Gyx3 \\
\hline 11 & 77 & 7 & No & $50 / 62.5$ & 289.92/34.99 & No & No & Liver & $\mathrm{BSC}$ \\
\hline 12 & 58 & $4 \mathrm{R}$ & Yes & $50 / 62.5$ & $141.27 / 95.95$ & No & No & Brain & 3 SRS 20 Gy \\
\hline 13 & 69 & $4 \mathrm{R}, 10 \mathrm{R}$ & Yes & $50 / 62.5$ & $121.91 / 50.37$ & No & 7 & Bone & $\mathrm{CT}$ \\
\hline 14 & 69 & $4 \mathrm{R}$ & Yes & $50 / 62.5$ & $134.19 / 19.86$ & No & No & Lung, nodes & BSC \\
\hline
\end{tabular}


Table 5 Summary of literature on toxicity and relative doses in salvage radiotherapy for locoregional recurrent NSCLC after surgery

\begin{tabular}{|c|c|c|c|c|c|c|c|c|c|}
\hline Author & $\begin{array}{l}\text { Type of } \\
\text { study }\end{array}$ & $\begin{array}{l}\mathrm{N}^{\circ} \text { of } \\
\text { patients }\end{array}$ & $\begin{array}{l}\text { Time } \\
\text { period }\end{array}$ & Median FUP & $\begin{array}{l}\text { RT } \\
\text { technique }\end{array}$ & Treatment volume & $\begin{array}{l}\text { Median } \\
\text { Dose } \\
\text { (Gy) } \\
\end{array}$ & $\begin{array}{l}\text { Concurrent } \\
\text { chemotherapy } \\
\left(n^{\circ}\right)\end{array}$ & Toxicity (\%) \\
\hline $\begin{array}{l}\text { Kagami } \\
\text { et al., } \\
1998 \text { [20] }\end{array}$ & Retrospective & 32 & $\begin{array}{l}1981- \\
1991\end{array}$ & n.s. & $\begin{array}{l}\text { AP-PA until } \\
40 \text { Gy, then } \\
\text { opposite } \\
\text { oblique } \\
\text { technique }\end{array}$ & PTV: GTV (margins n.s.) & $47.5-65$ & - & No G3 \\
\hline $\begin{array}{l}\text { Uno et al., } \\
2005 \text { [21] }\end{array}$ & Retrospective & 21 & $\begin{array}{l}2000- \\
2004\end{array}$ & 2-8 months & 3D-CRT & $\begin{array}{l}\text { PTV1: uninvolved } \\
\text { mediastinal and } \\
\text { ipsilateral hilar } \\
\text { lymphnodes+ } \\
\text { 10-15 mm } \\
\text { PTV2:GTV + } 10 \mathrm{~mm}\end{array}$ & $\begin{array}{l}60 \\
(46-60)\end{array}$ & $\begin{array}{l}\text { wCBDCA (7) } \\
\text { wCBDCA-PTX } \\
(2) \\
\text { wCBDCA-VDS } \\
(1) \\
\text { wCBDCA-VNB } \\
(1) \\
\text { wCDDP (1) }\end{array}$ & $\begin{array}{l}\text { Pneumonitis G3 (4.7) } \\
\text { Hematologic G3 } \\
\text { (4.7) } \\
\text { Hematologic G4 } \\
(4.7)\end{array}$ \\
\hline $\begin{array}{l}\text { Kelsey } \\
\text { et al., } \\
2006 \text { [22] }\end{array}$ & Retrospective & 29 & $\begin{array}{l}1991- \\
2003\end{array}$ & n.s. & n.s. & $\begin{array}{l}\text { PTV: ENI (27/29; n.s. } \\
\text { in others) }\end{array}$ & $\begin{array}{l}66 \\
(46-74)\end{array}$ & $\begin{array}{l}\text { NAD to RT (7) } \\
\text { Concomitant } \\
\text { (8) }\end{array}$ & $\begin{array}{l}\text { Esophagitis + } \\
\text { stenosis G3 (6.8) }\end{array}$ \\
\hline $\begin{array}{l}\text { Bae et al., } \\
2012\end{array}$ & Retrospective & 64 & $\begin{array}{l}1994- \\
2007\end{array}$ & 32 months & 3D-CRT & PTV: GTV + 10-20 mm & $\begin{array}{l}\text { Median } \\
\text { BED }_{10} 70.2 \\
(51.5-85.8)\end{array}$ & $\begin{array}{l}\text { wCDDP-PTX } \\
(12) \\
\text { CDDP-Eto q28 } \\
(2)\end{array}$ & $\begin{array}{l}\text { Pneumonitis } \\
\text { G3 (9.4\%) } \\
\text { Pneumonitis } \\
\text { G4 (1.6\%) }\end{array}$ \\
\hline $\begin{array}{l}\text { Bar et al., } \\
2013 \text { [18] }\end{array}$ & Retrospective & 30 & $\begin{array}{l}1999- \\
2007\end{array}$ & n.s. & $\begin{array}{l}\text { 3D-CRT } \\
(43)\end{array}$ & n.s. & $\begin{array}{l}63.5 \\
(26-66)\end{array}$ & $\begin{array}{l}\text { CDDP-VNL } \\
\text { q21 (14) } \\
\text { wCBDCA-PTX } \\
\text { (7) } \\
\text { CDDP-Eto q } \\
21 \text { (4) } \\
\text { Other platinum } \\
\text { reg. (5) }\end{array}$ & $\begin{array}{l}\text { Pneumonitis G3 (7) } \\
\text { Pneumonitis G4 (3.5) } \\
\text { Esophagitis G3 (14) } \\
\text { Febrile neutropenia } \\
\text { (14) } \\
\text { Esophageal stenosis } \\
\text { (7) } \\
\text { Other G3/4 (5/1): } \\
\text { hearing loss (2), } \\
\text { depression (1), } \\
\text { neuropathy (1), } \\
\text { nausea (1), } \\
\text { pulmonary } \\
\text { embolus (1) }\end{array}$ \\
\hline $\begin{array}{l}\text { Lee et al., } \\
2013[14]\end{array}$ & Retrospective & 38 & $\begin{array}{l}2001- \\
2009\end{array}$ & 26.4 months & 3D-CRT & $\begin{array}{l}\text { PTV: GTV + } 10 \mathrm{~mm} \text { for } \\
\text { the CTV }+5-15 \mathrm{~mm} \\
\text { Ipsilateral hilum usually } \\
\text { included, }\end{array}$ & $\begin{array}{l}\text { Median } \\
\text { BED }_{10} 74.4 \\
(58.5-97.5)\end{array}$ & $\begin{array}{l}\text { CDDP-Eto (9) } \\
\text { CBDCA-PTX (3) }\end{array}$ & $\begin{array}{l}\text { Esophagitis } \\
\text { G3 }(2.6 \%)\end{array}$ \\
\hline $\begin{array}{l}\text { Takenada } \\
\text { et al., } 2015\end{array}$ & Retrospective & 35 & $\begin{array}{l}2000- \\
2011\end{array}$ & n.s. & n.s. & n.s. & $60(30-60)$ & $\begin{array}{l}\text { CDDP-S1 (11) } \\
\text { CDDP-Tegafur- } \\
\text { Uracil (8) } \\
\text { CBDCA-VNL (10) } \\
\text { Other CDDP } \\
\text { reg. (4) } \\
\text { Other CBDCA } \\
\text { reg. (2) }\end{array}$ & $\begin{array}{l}\text { Esophagitis G3 (9) } \\
\text { Neutropenia G3 (14) } \\
\text { Neutropenia G4 (20) } \\
\text { Cardiac G3 (2) } \\
\text { Miscellaneous } \\
\text { infection (9) } \\
\text { Other G3 (11) }\end{array}$ \\
\hline $\begin{array}{l}\text { Kim et al., } \\
2017 \text { [13] }\end{array}$ & Retrospective & 57 & $\begin{array}{l}2004- \\
2014\end{array}$ & 53.6 months & 3D-CRT & $\begin{array}{l}\text { PTV: GTV }+5-8 \mathrm{~mm} \text { for } \\
\text { the CTV }+10 \mathrm{~mm}\end{array}$ & $\begin{array}{l}\text { Median } \\
\text { BED } 1079.2 \\
(58.5-84)\end{array}$ & $\begin{array}{l}\text { WCDDP-PTX (40) } \\
\text { CDDP-Eto q21 } \\
\text { (2) }\end{array}$ & $\begin{array}{l}\text { Pneumonitis G3 (5.3) } \\
\text { Esophagitis G3 (3.5) }\end{array}$ \\
\hline $\begin{array}{l}\text { Nakamichi } \\
\text { et al., } \\
2017 \text { [19] }\end{array}$ & Retrospective & 74 & $\begin{array}{l}2000- \\
2010\end{array}$ & n.s. & n.s. & $\begin{array}{l}\text { Lung lesions+recurrent } \\
\text { lymphnodes+regional } \\
\text { nodes }\end{array}$ & $\begin{array}{l}\text { Median } \\
60(50-70)\end{array}$ & $\begin{array}{l}\text { CDDP-VNL q28 } \\
(14) \\
\text { CBDCA-PTX (3) } \\
\text { CDDP-PTX (1) }\end{array}$ & $\begin{array}{l}\text { RT group (56): } \\
\text { Pneumonitis G3 (5) } \\
\text { Late pulm. } \\
\text { Toxicity (2) } \\
\text { Other non- } \\
\text { hematologic (2) } \\
\text { R-CT group (18): } \\
\text { Febrile neutropenia } \\
\text { (17) } \\
\text { Pneumonitis G3 } \\
\text { (5) } \\
\text { Esophagitis Ge }\end{array}$ \\
\hline
\end{tabular}


Table 5 Summary of literature on toxicity and relative doses in salvage radiotherapy for locoregional recurrent NSCLC after surgery (Continued)

\begin{tabular}{|c|c|c|c|c|c|c|c|c|c|}
\hline Author & $\begin{array}{l}\text { Type of } \\
\text { study }\end{array}$ & $\begin{array}{l}\mathrm{N}^{\circ} \text { of } \\
\text { patients }\end{array}$ & $\begin{array}{l}\text { Time } \\
\text { period }\end{array}$ & Median FUP & $\begin{array}{l}\text { RT } \\
\text { technique }\end{array}$ & Treatment volume & $\begin{array}{l}\text { Median } \\
\text { Dose } \\
\text { (Gy) }\end{array}$ & $\begin{array}{l}\text { Concurrent } \\
\text { chemotherapy } \\
\left(n^{\circ}\right)\end{array}$ & Toxicity (\%) \\
\hline & & & & & & & & & $\begin{array}{l}\text { Other non- } \\
\text { hematologic (5) }\end{array}$ \\
\hline $\begin{array}{l}\text { Seol et al., } \\
2017 \text { [16] }\end{array}$ & Retrospective & 31 & $\begin{array}{l}2008- \\
2013\end{array}$ & 14 months & 3D-CRT & $\begin{array}{l}\text { PTV: GTV + 10-20 mm } \\
\text { + adjacent nodal areas } \\
\text { (mediastinal and hilar) } \\
\text { considered at risk+ } \\
3-5 \mathrm{~mm}\end{array}$ & $\begin{array}{l}66 \\
(51-66)\end{array}$ & $\begin{array}{l}\text { NAD CT (7) } \\
\text { Concomitant } \\
C T(7) \\
\text { NAD CT + } \\
\text { R-CT (1) } \\
\text { RT + Adj CT (1) }\end{array}$ & Pneumonitis G3 (3.2) \\
\hline $\begin{array}{l}\text { Nicosia } \\
\text { et al. } \\
\text { (present } \\
\text { study) }\end{array}$ & Retrospective & 14 & $\begin{array}{l}2014- \\
2016\end{array}$ & 12 months & IMRT-SIB & $\begin{array}{l}\text { PTV1: GTV + } 5 \mathrm{~mm} \\
\text { PTV2: involved nodal } \\
\text { station + adjacent } \\
\text { stations and hilum + } \\
7 \mathrm{~mm}\end{array}$ & $\begin{array}{l}50+\text { boost } \\
62.5\end{array}$ & wCDDP (9) & Pneumonitis G3 (7.1) \\
\hline
\end{tabular}

NSCLC: non-small cell lung cancer; FUP: follow-up; CT: chemotherapy; AP-PA: antero-postero parallel opposite technique; 3D-CRT: 3-dimensional conformal radiotherapy; $N A D$ : neoadiuvant; $B E D$ : biological equivalent dose; $R-C T$ : radio-chemotherapy; $A d j$ : adjuvant; $C B D C A$ : carboplatin; $P T X$ : paclitaxel; VDS: vindesine; VNB: vinorelbine; $C D D P$ : cisplatin; Eto: etoposide

The rationale of treating NSCLC patients with mediastinal nodal relapse retain in the oligometastatic concept: patients with limited metastatic disease may benefit from more aggressive local treatment to the macroscopical disease. Recent series suggest that survival of loco-regional recurrent NSCLC is more similar to that of stage III NSCLC than to stage IV. Therefore, it is conceivable that a dose of RT $>66 \mathrm{~Gy}$ and the addition of systemic therapy may improve local control having a favorable effect on survival [1, 14-17].

Bar et al. [18] treated 30 patients with different RT schedules (median dose 63.5 Gy) and platinum-based chemotherapy obtaining a response rate of $70 \%$ and 2and 3-years overall survival (OS) of $50.8 \%$ and $38.7 \%$, respectively. Nakamichi et al. [19] reported a series of 74 patients treated with RT alone 60 Gy (56 patients) or RT 60 Gy associated to concomitant chemotherapy (18 patients). The response rate after RT alone and combined therapy were $68 \%$ and $78 \%$, respectively, and the use of the concomitant chemotherapy predicted for better OS and PFS. The median OS for RT alone and radiochemotherapy patients were 33.1 and 79.6 months, respectively, and the 5 -years OS were $35 \%$ and $53 \%$, respectively. Kim et al. [13] reported rates of 2-years LRFS and OS of $70.9 \%$ and $62.4 \%$, respectively. Treatment failure globally occurred in $68.4 \%$ of patients with $8.8 \%$ of isolated infield failure.

Local control of our series was in line with previous studies with $50 \%$ of complete response at 1 -year, median LPFS of 26 months and 1- and 2-years LPFS of $80 \%$ and $40 \%$, respectively. In-field recurrence occurred all within the 50 Gy volume, so that the dose in the boost volume seems adequate to control the macroscopical disease, even if a longer follow-up would be required.
The contribution of metastatic spread was difficult to assess in this series, also considering that the analysis of survival was beyond the intentions of this pilot study. Metastatic spread occurred in $50 \%$ of patients after a median of 9 months. This could be in accordance with two hypothesis: first of all, it was a disseminated disease from the beginning, and second of all, there was poor efficacy of the concomitant chemotherapy. We are more likely to consider the second option as more plausible, since we accurately staged all the patients before treatment with CT scan and 18FDG-PET/CT. Moreover, the systemic control of previous studies, where regimens more intensive were administered, are consistent with this hypothesis.

To our knowledge this is the first study that reported the use of IMRT-SIB in a population of mediastinal nodal recurrent NSCLC. Our preliminary data, taking into account the retrospective nature of the study, showed optimal tolerance and promising local control. A phase II study with a larger population is mandatory to assess the effect of a more intensive concomitant chemotherapy regimen that could synergize with the proposed fractionation delivered with modern and precise techniques, with the aim to improve survival and minimize side effects.

\section{Conclusions}

Aggressive local therapy associated to systemic therapy could be a good option in the treatment of postoperative mediastinal nodal relapse in NSCLC patients unfit to receive a second surgery. In this particular population of oligometastatic NSCLC patients, a modern radiotherapy delivered with accurate techniques and a combined systemic approach may lead to good outcome and tolerability. Better distant control might be obtained with more intensified systemic therapy and should be prospectively evaluated in a larger series. 


\section{Abbreviation}

18FDG-PET: 18fluorodeoxyglucose-positron emission tomography; 3D-CRT: 3dimensional conformal radiotherapy; Adj: Adjuvant; AP-PA: Antero-postero parallel opposite technique; BED: Biological equivalent dose; BSC: Best supportive care; CBDCA: Carboplatin; CCT: Concomitant chemotherapy; CDDP: Cisplatin; COPD: Chronic obstructive pulmonary disease; CR: Complete response; CT: Computed tomography; CTCAE: Common Terminology Criteria for Adverse Events; CTV: Clinical target volume; Eto: Etoposid; FUP: Follow-up; GTV: Gross target volume; ILL: Inferior left lobe; IMRT: Intensity-modulated radiation therapy; IRL: Inferior right lobe; LPFS: Local progression-free survival; MFS: Metastasis-free survival; ML: Middle lobe; MLD: Mean lung dose; NAD: Neoadiuvant; NSCLC: Non-small cell lung cancer; OS: Overall survival; PFS: Progression-free survival; PORT: Post-operative radiation therapy; PTV: Planning target volume; PTX: Paclitaxel; R-CT: Radio-chemotherapy; RT: Radiotherapy; SIB: Simultaneous integrated boost; SLL: Superior left lobe; SRL: Superior right lobe; SRS: Stereotactic radiosurgery; VDS: Vindesine; VNB: Vinorelbine

\section{Acknowledgements}

The authors would like to thank Prof. Grace Xerri for her help in the final revision of the manuscript.

\section{Availability of data and materials}

The datasets used and/or analysed during the current study are available from the corresponding author on reasonable request.

\section{Authors' contributions}

LN analyzed and interpreted patients data, wrote the manuscript. LA analyzed data and was a major contributor in writing the manuscript. CR collected patient data and wrote Material and Methods chapter. VD Contributed to write the manuscript and LM collected patient data. GM Statistical analysis. JD revised the literature, compiled tables and revised the manuscript. MV Statistical analysis and contributor in writing the manuscript. MO Definition of protocol parameters and final revision of manuscript. All authors read and approved the final manuscript.

\section{Ethics approval and consent to participate}

Not applicable.

\section{Consent for publication}

Not applicable.

\section{Competing interests}

The authors declare that they have no competing interests.

\section{Publisher's Note}

Springer Nature remains neutral with regard to jurisdictional claims in published maps and institutional affiliations.

\section{Author details}

'Department of Radiation Oncology, Sant'Andrea Hospital, "Sapienza" University of Rome, Via di Grottarossa 1035-1039, 00189 Rome, Italy. ${ }^{2}$ Department of Radiation Oncology, Faculty of Medicine, University Hospital Carl Gustav Carus, Technische Universität Dresden, Dresden, Germany. ${ }^{3}$ Radiation Oncology Unit, UPMC Hillman Cancer Center, San Pietro Hospital, Rome, Italy. ${ }^{4}$ RCCS Neuromed, Pozzilli (IS), Italy. ${ }^{5}$ Department of Oncology, Radiation Oncology, University of Torino, Torino, Italy.

Received: 20 March 2018 Accepted: 11 October 2018

Published online: 23 October 2018

\section{References}

1. Goldstraw P, Chansky K, Crowley J, Rami-Porta R, Asamura H, Eberhardt WE, Nicholson AG, Groome P, Mitchell A, Bolejack V. The IASLC lung Cancer staging project: proposals for revision of the TNM stage groupings in the forthcoming (eighth) edition of the TNM classification for lung Cancer. J Thorac Oncol. 2016;11(1):39-51. https://doi.org/10.1016/j.jtho.2015.09.009.

2. Taylor MD, Nagji AS, Bhamidipati CM, et al. Tumor recurrence after complete resection for non-small cell lung cancer. Ann Thorac Surg. 2012;93:1813-20.
3. Saynak M, Veeramachaneni NK, Hubbs JL, et al. Local failure after complete resection of N0-1 non-small cell lung cancer. Lung Cancer. 2011;71:156-65.

4. Kelsey CR, Marks LB, Hollis D, et al. Local recurrence after surgery for early stage lung cancer: an 11-year experience with 975 patients. Cancer. 2009; 115:5218-27.

5. Burdett S, Rydzewska L, Tierney J, Fisher D, Parmar MKB, Arriagada R, Pignon JP, Le Pechoux C, on behalf of the PORT meta-analysis Trialists group. Postoperative radiotherapy for non-small cell lung cancer. Cochrane Database Syst Rev. 2016;10:CD002142.

6. Corbin KS, Hellman S, Weichselbaum RR. Extracranial oligometastases: a subset of metastases curable with stereotactic radiotherapy. J Clin Oncol. 2013:31:1384-90.

7. Niibe Y, Hayakawa K. Oligometastases and oligo-recurrence: the new era of cancer therapy. Jpn JClin Oncol. 2010;40:107-11.

8. Huang F, Wu G, Yang K. Oligometastasis and oligo-recurrence: more than a mirage. RadiatOncol. 2014;9:230.

9. Pfannschmidt J, Dienemann H. Surgical treatment of oligometastatic nonsmall cell lung cancer. Lung Cancer. 2010;69:251-8.

10. Tanvetyanon T, Robinson LA, Schell MJ, Strong VE, Kapoor R, Coit DG, et al. Outcomes of adrenalectomy for isolated synchronous versus metachronous adrenal metastases in non-small- cell lung cancer: a systematic reviewand pooled analysis. J Clin Oncol. 2008;26:1142-7.

11. Yamashita $H$, Niibe $Y$, Yamamoto $T$, et al. Lung stereotactic radiotherapy for oligometastases: comparison of oligorecurrence and sync-oligometastases. Jpn J Clin Oncol. 2016;46:687-91.

12. Bae SH, Ahn YC, Nam H, Park HC, Pyo HR, Shim YM, Kim J, Kim K, Ahn JS, Ahn MJ, Park K. High dose involved field radiation therapy as salvage for loco-regional recurrence of non-small cell lung cancer. Yonsei Med J. 2012; 53(6):1120-7. https://doi.org/10.3349/ymj.2012.53.6.1120.

13. Kim E, Song C, Kim MY, Kim JS. Long-term outcomes after salvage radiotherapy for postoperative locoregionally recurrent non-small-cell Lung Cancer Radiat Oncol J 2017;35(1):55-64. https://doi.org/10.3857/roj. 2016.01928. Epub 2017 Feb 13.

14. Lee NK, Moon SH, Kim TH, Han JY, Yun T, Kim HT, Lee HS, Kim MS, Lee JM, Cho KH, Lee JS. Prognostic value of gross tumor volume for definitive radiation therapy in patients with locoregionally recurrent non-small-cell lung cancer after surgical resection. Clin Lung Cancer. 2013;14(4):399-406. https://doi.org/10.1016/j.cllc.2012.11.002. Epub 2012 Dec 29.

15. Takenaka T, Takenoyama M, Toyozawa R, Inamasu E, Yoshida T, Toyokawa G, Shiraishi Y, Hirai F, Yamaguchi M, Seto T, Ichinose Y. Concurrent chemoradiotherapy for patients with postoperative recurrence of surgically resected nonsmall-cell lung cancer. Clin Lung Cancer. 2015;16(1):51-6. https://doi.org/ 10.1016/j.cllc.2014.06.001. Epub 2014 June 21.

16. Seol KH, Lee JE, Cho JY, Lee DH, Seok Y, Kang MK. Salvage radiotherapy for regional lymph node oligo-recurrence after radical surgery of non-small cell lung cancer. Thorac Cancer. 2017;8(6):620-9. https://doi.org/10.1111/17597714.12497. Epub 2017 Sept 14.

17. Yoon SM, Shaikh T, Hallman M. Therapeutic management options for stage III non-small cell lung cancer. World J Clin Oncol. 2017:8:1-20.

18. Bar J, Ng D, Moretto P, Goss GD, Sun A, Macrae R, Laurie SA, Leighl N, Nicholas $\mathrm{G}$. Chemoradiotherapy for locoregional recurrence of non-smallcell lung cancer after surgical resection: a retrospective analysis. Clin Lung Cancer. 2013;14(2):200-4. https://doi.org/10.1016/j.cllc.2012.05.008. Epub 2012 Aug 4.

19. Nakamichi S, Horinouchi H, Asao T, Goto Y, Kanda S, Fujiwara Y, Nokihara H, Yamamoto N, Ito Y, Watanabe SI, Ohe Y. Comparison of radiotherapy and Chemoradiotherapy for Locoregional recurrence of non-small-cell lung Cancer developing after surgery. Clin Lung Cancer. 2017;18(6):e441-8. https://doi.org/10.1016/j.cllc.2017.05.005. Epub 2017 May 10.

20. Kagami Y, Nishio M, Narimatsu N, Mjoujin M, Sakurai T, Hareyama M, Saito A. Radiotherapy for locoregional recurrent tumors after resection of non-small cell lung cancer. Lung Cancer. 1998;20(1):31-5.

21. Uno T, Isobe K, Kawakami H, Ueno N, Kawata T, Yamamoto S, Sekine Y, lyoda A, lizasa T, Fujisawa T, Shigematsu N, Ito H. Dose-volume factors predicting radiation pneumonitis in patients receiving salvage radiotherapy for postlobectomy locoregional recurrent non-small-cell lung cancer. Int J Clin Oncol. 2006;11(1):55-9.

22. Kelsey CR, Clough RW, Marks LB. Local recurrence following initial resection of NSCLC: salvage is possible with radiation therapy. Cancer J. 2006;12(4):283-8. 